\title{
DO RIO DAS VITRINES À GALERIA DOS DESCONHECIDOS: UM ESTUdO EM PSICOLOGIA Social Comunitária na localidade de Muzema
}

Lurdes Perez Oberg

A presente tese tem, como propósito, investigar a relevância e adequação da Psicologia Comunitária no atendimento a populações de baixa renda. A partir de uma experiência no Posto de Saúde, na localidade de Muzema, Zona Oeste da cidade do Rio de Janeiro, foram realizadas 12 entrevistas com mulheres da comunidade, entrevistas nas quais se fizeram reflexóes sobre temas da cultura contemporânea. As falas das entrevistadas foram entendidas à luz das teorias utilizadas sempre articuladas à realidade vivida. Apresentando um referencial teórico sóciohistórico apresentamos a comunidade como um microcosmo de um contexto mais amplo de análise. A tese ressalta, ainda, a possibilidade de realização de um trabalho clínico que se não se esgota em consultório privados mas que pode ser praticado em contextos mais amplos e diversos.

\section{BANCA:}

Junia de Vilhena (Orientadora)

Hebe Signorini Gonçalves

Maria Helena Rodrigues Navas Zamora

Raquel Souza Lobo Guzzo

Tereza Maria Pompéia Cavalcanti

Data de defesa: 28/09/2007 